\title{
INTELLIGENT GAS BOOKING AND LEAKAGE SYSTEM USING WIRELESS SENSOR NETWORKS
}

Kalpana Murugam

Department of Electronics and Communication Engineering,

School of Electronics and Electrical Technology,

Kalasalingam Academy of Research and Education,

Krishnankoil, Virudhunagar Dt., (India).

E-mail: drmkalpanaece@gmail.com ORCID: https://orcid.org/0000-0002-5121-0468

\section{Citación sugerida:}

Murugam, K. (2020). Intelligent gas booking and leakage system using wireless sensor networks. 3C Tecnología. Glosas de innovación aplicadas a la pyme. Edición Especial, Marzo 2020, 273-285. http://doi. org/10.17993/3ctecno.2020.specialissue4.273-285

\section{Suggested citation:}

Murugam, K. (2020). Intelligent gas booking and leakage system using wireless sensor networks. 3C Tecnología. Glosas de innovación aplicadas a la pyme. Edición Especial, Marzo 2020, 273-285. http://doi. org/10.17993/3ctecno.2020.specialissue4.273-285 


\section{ABSTRACT}

Nowadays the technology is rapidly growing, and human life is becoming easier than the past. In our country maximum number of people is using LPG (Liquid Petroleum Gas) in several places like houses, shops and in many industries. To assemble of LPG is too diminutive. But it is very difficult to the illiterate people to understand and many of the people in our society is busy with their works, so that they can't know the status of the gas and if the booking of the LPG gets delay then it will be uncomfortable to the people. In order to overcome this problem, Intelligent Gas booking and Leakage Detection System (IGLS) is proposed. When the LPG gas gets minimum weight then GSM drive the memo to the owner and warns about the LPG gas is getting over, so that the owner tries to book the LPG in advance. Huge numbers of people are facing the gas leakage problem. In order to avoid this drawback, a gas sensor is utilized to sense the gas outflow and switch ON the buzzer and sends a message of outflow of the gas to warn the owner. Proposed system will be benefitted for society.

\section{KEYWORDS}

Gas sensor, Gas detector, Wireless Sensor networks, LCD display, Load cell, Buzzer, Arduino board. 


\section{INTRODUCTION}

LPG is known as Liquid Petroleum Gas. In Arpitha, Kiran, Gupta, and Duraiswamy (2016) consists of saturated propane and saturated butane mixture as well as unsaturated hydrocarbons. In LPG, Ethanethiol is added (Macker, Shukla, Dey, \& Agarwal, 2018). So that it becomes odourless gas, which will easily detect leakage of gas. In our country (Varma, Prabhakar, \& Jayavel, 2017) there are approximately 40 crore people are using LPG which is nearly $45 \%$ of our population. In Shinde, Patil, and Patil (2012), and Mahalingam, Naayagi, and Mastorakis (2012), LPG gas, which is commercially used in domestic area for heating, cooking, shops and industrial purpose, etc., LPG has highly flammable because of the mixture of propane and butane. In Priya, Surekha, Preethi, Devika, and Dhivya (2014) a cylinder is to be found that it is loaded, which will measure the weight of the cylinder. In Ramya and Palaniappan (2012) inserted a minimum weight of the cylinder according to the level of a gas.

\section{RELATED WORK}

In Shyamaladevi, Rajaramya, Rajasekar, and Ashok (2014) proposed a structure that will make the whole LPG compartment booking system robotized was excluded human intervention. This framework ceaselessly decides the greatness of the chamber drive notice to the insisted LPG agent with the target that they can pass on the LPG chamber in time.

In Cheung, Lin, and Lin (2018) consolidates WSN into an astounding structure which enables the structure site to ostensibly screen the prosperity status by methods for a spatial, concealed interface and empty any perilous gas normally. In Dewi and Somantri (2018) were proposed the inspiration driving this structure is to recognize gas spillage, murder it, and thwart the impact. WSN framework works were reliant on gas sensor MQ-6 and remote module Bluetooth HC-05. Impact neutralizing activity system works reliant on the alarm/ringer, exhaust fan, and customized gas controller.

In Hema, Murugan, and Chitra (2013) the light was unmistakable tangibility and common confinements of different gas identifying developments, experts have been managing different circumstances with overhauled frameworks. In this, they were analyzed the overview of progressed enhancement in leakage of gas recognizing. In Kalaivanan and 
Manoharan (2016) were the essential objectives of the endeavor is to gather a Gas spillage discoverer using LPG gas sensor and furthermore it was interface with IoT using ESP module for security. A solenoid is set such a way, that at whatever point there is a sign, it will close the pipe to stop the movement of gas.

In Padmapriya and Kamini (2013) the structure also is used for other application in the business or plant that depends upon LPG and vaporous oil in their action this endeavor is used to screen relentless load of the LPG chamber. In our country customarily that people don't know decisively the status of the chamber and there is a deferment in lighting up gas office. To keep far from such conditions have completed the endeavor called "Customized Gas Booking Using Embedded System with Safety Guards". In this endeavor used weight cell as a weight sensor. MQ6 as an LPG spillage sensor which will recognize the spillage of LPG and offers security to people. The gas office gets the solicitation of new chamber and owner got the messages regarding the status. In paper (Apeh, Erameh, \& Iruansi, 2014) were smoke sensor was used to recognize gas spillage in the home. In case any gas spillage recognized subsequently, it will send SMS to the fire station. GSM is a champion among the most cell frameworks used in India. In our endeavor, we have used weight cell to screen the hold up of the LPG gas routinely. In Bangali and Shaligram (2013) proposes the Internet of Things is considered as the third surge of information development straightforwardly after Internet and flexible correspondence sort out, which is depicted by progressively complete interoperability and learning. By this creative progress, it engages us to screen the activities through our propelled cell phones, to share information.

In Potadar, Salvi, Sathe, and Chavan (2015) proposes the system will recognize the spillage and exhort the client about the gas spillage by SMS Audio yield is moreover made on speaker. As a bit of emergency, the system will immediately temperament executioner the control valve with the help of stepper motor to evade a mishap. The additional good position of the system is that it constantly screens the component of the LPG present in the chamber using load cell and demonstrate the weight always. The programmed gas booking framework will really discard call stopping or dialing such countless numbers while booking the gas chamber. 
In Ravichandran (2017) were LPG will finish without instructing us it can make an inconvenient condition for cooking, etc. Our arrangement relies upon ARM controller, it can pursue LPG void continually in case LPG is close culmination or at void measurement, by then, it can alert us by sending SMS to LPG Agency for mentioning the LPG chamber. In Imade, Rajmanes, Gavali, and Nayakwadi (2018) were analyzed, the fundamental stress of any assignment has not been left impeccable by IoT. In Khan, Prince, Dewangan, and Rathore (2014), Gas Leakages in open or shut districts can show to be dangerous and savage. The customary Gas Leakage Detector Systems have various phenomenal precision; disregard to perceive two or three segments in the field of disturbing the all-inclusive community about the spillage. In Jolhe, Potdukhe, and Gawai (2013) in the unlikely event that LPG is going to complete without teaching us, it can make an irksome condition for cooking, etc. Our structure relies upon the microcontroller, it can pursue LPG void continually in case LPG is especially near completion or at void measurement, by then it can alert us by sending SMS to the owner and it can in like manner move the message to LPG Agency for mentioning the LPG chamber.

\section{PROPOSED SYSTEM}

\subsection{INTELLIGENT GAS BOOKING AND LEAKAGE DETECTION SYSTEM (IGLS)}

Gas leakage means if the gas is transferred from one pipe to another pipe or other container of natural gas or another gas product may not be present. Leaks are very dangerous because a small leak can gradually produce an explosive concentration of gas. This is the main drawback of traditional gas leakage system. In order to overcome the above problem, this work proposes Intelligent Gas booking and Leakage Detection System (IGLS).

When the LPG gets to the base weight, the GSM sends the message to the proprietor by the assistance of Arduino. Arduino is accustomed to sending the message to the client with the assistance of GSM. The LCD shows the heaviness of the chamber consistently. This program is created to send the message through GSM to the given number of the client. The gas sensor MQ6 to detect the gas around the place, after that microcontroller automatically switch ON the signal and sends the message to the proprietor. 
The message sent to the fixed number automatically and access remotely with the assistance of GSM. At the point when the heaviness of the gas chamber gets least; GSM sends the message to the proprietor and cautions the proprietor about the leakage of the gas.

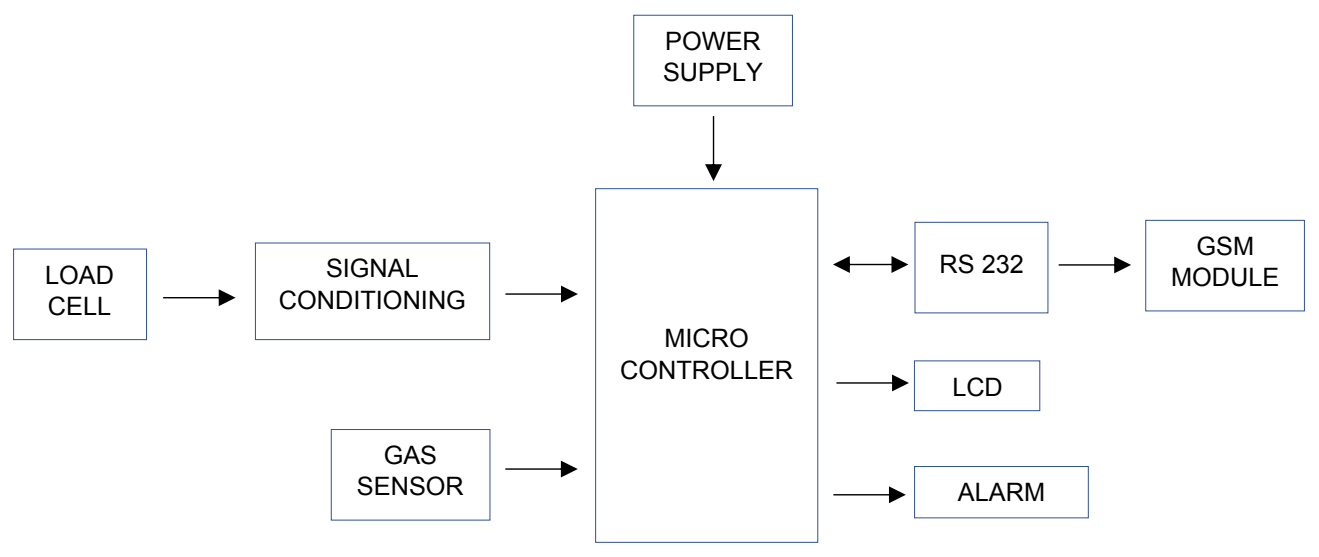

Graphic 1. BLOCK DIAGRAM.

\section{METHODOLOGY}

The main aim of this system is to estimate the GAS level and leakage of the gas from the room or an industry. The leakage of the gas will be estimated with the help of IGLS system using MQ6 gas sensor. This gas sensor senses the gas and sends the message to the user with the help of GSM module. Liquefied Petroleum Gas (LPG) sensor is simple and easy to detect the gas level. Gas sensor has fast response and high sensitivity module. Liquefied Petroleum Gas (LPG) sensor is simple and easy to detect the gas level. Gas sensor has fast response and high sensitivity.

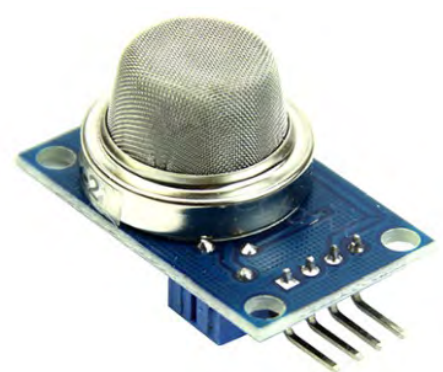

Graphic 2. PIR Sensor. 
Table 1. Specification of MQ6 sensor.

\begin{tabular}{|c|c|c|c|}
\hline \multicolumn{3}{|c|}{ Model No. } & MQ-6 \\
\hline \multicolumn{3}{|c|}{ Sensor Type } & Semiconductor \\
\hline \multicolumn{3}{|c|}{ Standard Encapsulation } & Bakelite (Black Bakelite) \\
\hline \multicolumn{3}{|c|}{ Detection Gas } & Isobutane, Butane, LPG \\
\hline \multicolumn{3}{|c|}{ Concentration } & $\begin{array}{c}300-10000 \text { ppm } \\
\text { (Butane, Propane, LPG) }\end{array}$ \\
\hline \multirow{3}{*}{ Circuit } & Loop Voltage & $\mathrm{V}_{\mathrm{c}}$ & $\leq 24 \mathrm{~V} \quad \mathrm{DC}$ \\
\hline & Heater Voltage & $\mathrm{V}_{\mathrm{H}}$ & $5.0 \mathrm{~V} \pm 0.2 \mathrm{~V}$ ACorDC \\
\hline & Load Resistance & $\mathrm{R}_{\mathrm{L}}$ & Adjustable \\
\hline \multirow{5}{*}{ Character } & Heater Resistance & $\mathrm{R}_{\mathrm{H}}$ & $31 \Omega \pm 3 \Omega$ (Room Tem.) \\
\hline & Heater consumption & $\mathrm{P}_{\mathrm{H}}$ & $\leq 900 \mathrm{~mW}$ \\
\hline & Sensing Resistance & $\mathrm{R}_{\mathrm{s}}$ & $2 \mathrm{~K} \Omega-20 \mathrm{~K} \Omega$ (in 2000ppm C3H8) \\
\hline & Sensitivity & S & Rs (in air) / Rs (1000ppm C4H10) $\geq 5$ \\
\hline & Slope & $\alpha$ & $\leq 0.6$ (R2000ppm / R1000ppm LPG) \\
\hline \multirow{3}{*}{ Condition } & \multicolumn{2}{|c|}{ Tem. Humidity } & $20^{\circ} \mathrm{C} \pm 2^{\circ} \mathrm{C} ; 65 \% \pm 5 \% \mathrm{RH}$ \\
\hline & \multicolumn{2}{|c|}{ Standard test circuit } & $\mathrm{V}_{\mathrm{c}}: 5.0 \mathrm{~V} \pm 0.1 \mathrm{~V} ; \mathrm{V}_{\mathrm{H}}: 5.0 \mathrm{~V} \pm 0.1 \mathrm{~V}$ \\
\hline & \multicolumn{2}{|c|}{ Preheat time } & Over 48 hours \\
\hline
\end{tabular}

\section{WORKING PRINCIPLE}

The working standard of this system has appeared in the square outline in Figure 1. The Arduino board is assuming an indispensable job which is utilized to quantify the parameters of gas and weight. Every one of the parts is associated with the Arduino board. Arduino gets the messages to the purchaser about the gas chamber like gas spillage and gas weight of the chamber. At the point when the gas is spilling from the gas chamber, the gas sensor will detect the gas spillage and after that sends the data to the Arduino then the Arduino will check the code and sends the data to the GSM module and ringer. The GSM module will send the short message too private the client to realize the gas is spilling and the ringer will make the noisy sound that underwear that gas is spilling. This work will screen with the assistance of GSM ceaselessly if the gas weight is low as for the given load in the code. The gas weight is recognized by the heap cell. The heap cell checks the heaviness of the chamber if the heaviness of the chamber is lower than the given code it will send the data to the Arduino board. It will give the direction to the GSM module to send the message to the customer that the gas weight is low and it starts the client to book the gas chamber. By utilizing the LCD show the weight and the gas spillage estimations of the chamber are shown routinely. 


\section{RESULT AND DISCUSSION}

Intelligent Gas booking and Leakage Detection System is implemented in real time. The gas weight and the gas spillage are estimated by utilizing IGLS, the estimated gas values are showed in the Liquid Crystal Display (LCD). The gas present in the room air before the gas spillage having the level is $0 \mathrm{ppm}$, which was appeared in the LCD. When the gas was spilled from the gas chamber the gas sensor will detect the gas in the room air. The GSM module will send the message to the individual proprietor of the user where the portable number was in the GSM module and sends the message "GAS WAS LEAKING". On and off messages send to the controller when the gas was not spilling from the gas chamber. Burden cell will detect the heaviness of the gas chamber. On and off message shows that the heaviness of the chamber is not exactly the edge weight, at that point, it will send the message to the user that the "GAS CYLINDER WEIGHT IS LOW BOOK THE GAS CYLINDER" was sent to the versatile number present in the GSM module. This system will be benefit able for society.

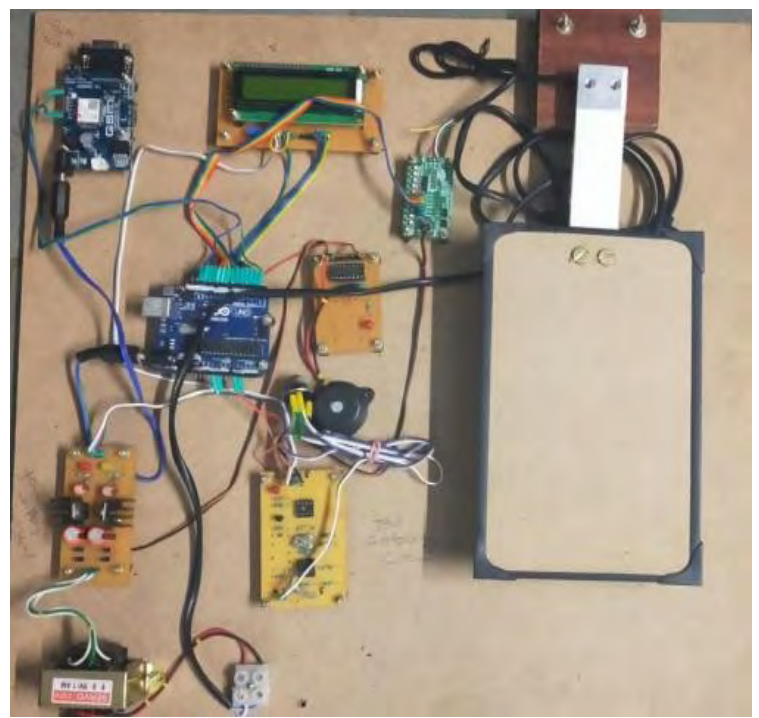

Graphic 3. Output for gas booking and leakage system System.

\section{CONCLUSION}

This project is based on the Intelligent gas booking system using wireless sensor networks and it is working well, and the main parameters of the Intelligent gas booking system is 
based on the safety purpose of the of day today life everyone are using the LPG gas for cooking and other purposes there is no safety in the place. This project will work nicely in any complex stages. During the design as well as the construction on it because to avoid the hiccups at the final stage. The layout was prepared with almost care to avoid wrong things in the circuit is made as simple as possible to understand easily to our knowledge. The components also taken care about these performance and cost effectiveness. It was interesting while preparing the project and some difficult at some stages it will be enthusiastic and easy to do the work on the project. This project is benefitted for society. 


\section{REFERENCES}

Apeh, S. T., Erameh, K. B., \& Iruansi, U. (2014). Design and Development of Kitchen Gas Leakage Detection and Automatic Gas Shut off System. Fournal of Emerging Trends in Engineering and Applied Sciences (JETEAS), 5(3), 222-228. http://jeteas. scholarlinkresearch.com/articles/Design \%20and\%20Development $\% 20$ of\%20 Kitchen\%20Gas\%20Leakage.pdf

Arpitha, T., Kiran, D., Gupta, V. S., \& Duraiswamy, P. (2016). FPGA-GSM based gas leakage detection system. IEEE Annual India Conference (INDICON), Bangalore, India, pp.1-4. IEEE. https://doi.org/10.1109/INDICON.2016.7838952

Bangali, J., \& Shaligram, A. (2013). Design and Implementation of Security Systems for Smart Home based on GSM technology. International Fournal of Smart Home, 7(6), 201-208. http://dx.doi.org/10.14257/ijsh.2013.7.6.19

Cheung, W. F., Lin, T. H., \& Lin, Y. C. (2018). A real-time construction safety monitoring system for hazardous gas integrating wireless sensor network and building information modeling technologies. Sensors, 18(2), 436. https://doi.org/10.3390/s18020436

Dewi, L., \& Somantri, Y. (2018). Wireless Sensor Network on LPG Gas Leak Detection and Automatic Gas Regulator System Using Arduino. In IOP Conference Series: Materials Science and Engineering, 384(1), 012064. https://doi.org/10.1088/1757899X/384/1/012064

Hema, L. K., Murugan, D., \& Chitra, M. (2013). WSN based Smart system for detection of LPG and Combustible gases. In National Conference on Architecture, Software systems and Green computing-2013. https://pdfs.semanticscholar. org/304f/541754fle24f8ed6fdf4c2750a1c771173aa.pdf

Imade, S., Rajmanes, P., Gavali, A., \& Nayakwadi, P. V. N. (2018). Gas leakage detection and smart alerting system using IOT. International fournal of Innovative research \& studies, 2(II). https://www.pramanaresearch.org/gallery/22.\%20feb\%20ijirs \%20 $-\% 20 d 539 . p d f$ 
Jolhe, B. D., Potdukhe, P. A., \& Gawai, N. S. (2013). Automatic LPG booking, leakage detection and real time gas measurement monitoring system. International Journal of Engineering Research \& Technology (IfERT), 2(4), 1192-1195. https://www. ijert.org/research/automatic-lpg-booking-leakage-detection-and-real-time-gasmeasurement-monitoring-system-IJERTV2IS4612.pdf

Kalaivanan, S., \& Manoharan, S. (2016). Monitoring and Controlling of Smart Homes using IoT and Low Power Wireless Technology. Indian fournal of Science and Technology, 9(31), 1-9. https://doi.org/10.17485/ijst/2016/v9i31/92701

Khan, A., Prince, N. K., Dewangan, S. K., \& Rathore, P. S. (2014). GSM based automatic LPG ordering system with leakage alert. IfRET: International fournal of Research in Engineering and Technology, 3. https:/ /www.academia.edu/8034393/GSM_ BASED_AUTOMATIC_LPG_ORDERING_SYSTEM_WITH_LEAKAGE_ ALERT

Macker, A., Shukla, A. K., Dey, S., \& Agarwal, J. (2018). ARDUINO Based LPG Gas Monitoring Automatic Cylinder Booking with Alert System. In 2nd International Conference on Trends in Electronics and Informatics (ICOEI), Tirunelveli, India. IEEE. 12091212. https://doi.org/10.1109/ICOEI.2018.8553840

Mahalingam, A., Naayagi, R. T., \& Mastorakis, N. E. (2012). Design and implementation of an economic gas leakage detector. Recent Researches in Applications of Electrical and Computer Engineering, 20-24. http://www.wseas.us/e-library/ conferences/2012/Vouliagmeni/ACA/ACA-02.pdf

Padmapriya, R., \& Kamini, E. (2013). Automatic LPG Booking, Leakage Detection and a Real Time LPG Measurement Monitoring System. https:/ / docplayer.net/8700630-Automaticlpg-booking-leakage-detection-and-a-real-time-lpg-measurement-monitoringsystem.html

Potadar, M. P., Salvi, P. S., Sathe, R. B., \& Chavan, P. S. (2015). LPG Leakage Detection and Automatic Gas Cylinder Booking System. International fournal of Engineering Research. 
Priya,K.P.,Surekha,M.,Preethi,R.,Devika,T., \&Dhivya,N.(2014).Smartgas cylinder using embedded system. International Fournal of Innovative Research in Electrical, Electronics, Instrumentation and Control Engineering (IFIREEICE), 2(2), 958-962. http://citeseerx.ist. psu.edu/viewdoc/download?doi=10.1.1.428.5116\&rep=rep 1\&type=pdf

Ramya, V., \& Palaniappan, B. (2012). Embedded system for Hazardous Gas detection and Alerting. International Fournal of Distributed and Parallel Systems (IFDPS), 3(3), 287300. https://doi.org/10.5121/ijdps. 2012.3324

Ravichandran, S. (2017). Cloud Connected Smart Gas Cylinder Platform Senses LPG Gas Leakage Using IoT Application. International fournal of MC Square Scientific Research (IFMSR), 9(1), 324-330. https://pdfs.semanticscholar.org/ bc5b/3982690389a19060c9dac08eb0df42ab3fec.pdf

Shinde, S., Patil, S. B., \& Patil, A. J. (2012). Development of movable gas tanker leakage detection using wireless sensor network based on embedded system. International Journal of Engineering Research and Application (IfTERA), 2(6), 1180-1183. http:// citeseerx.ist.psu.edu/viewdoc/download?doi=10.1.1.415.33\&rep=rep $1 \&$ type=pdf

Shyamaladevi, S., Rajaramya, V. G., Rajasekar, P., \& Ashok, P. S. (2014). Arm7 based automated high performance system for LPG refill booking \& leakage detection. International journal of engineering research, science and technology (IfERST), 3(2).

Varma, A., Prabhakar, S., \& Jayavel, K. (2017). Gas Leakage Detection and Smart Alerting and prediction using IoT. In 2nd International Conference on Computing and Communications Technologies (ICCCT), Chennai, India, pp. 327-333. IEEE. https://doi. org/10.1109/ICCGT2.2017.7972304 
